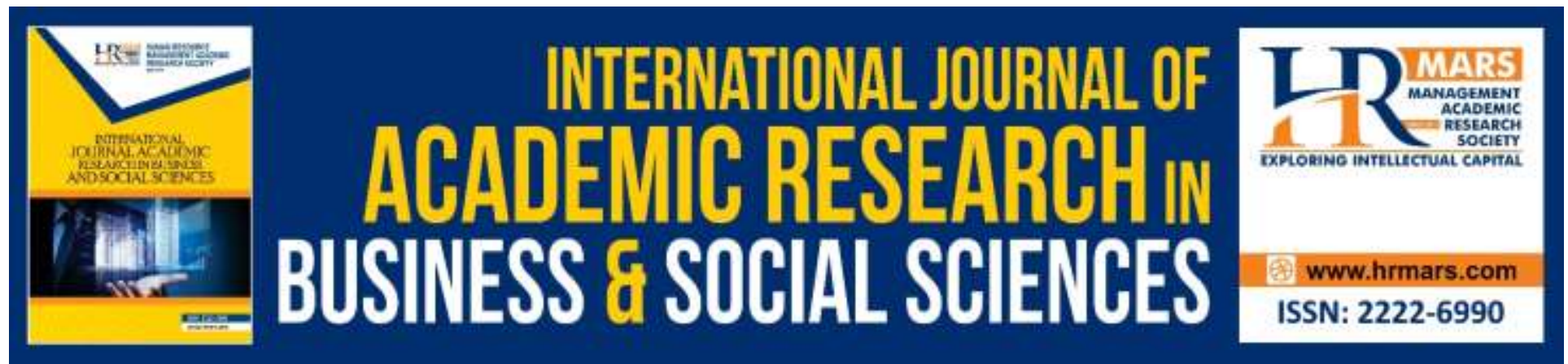

\title{
A Review of Board of Director, Shariah Supervisory Board and Zakat Distribution Performance in Malaysia
}

Norlizawati Abd Rahman, Mohd Abdullah Jusoh

To Link this Article: http://dx.doi.org/10.6007/IJARBSS/v8-i2/3985

DOI:10.6007/IJARBSS/v8-i2/3985

Received: 22 Dec 2017, Revised: 06 Feb 2018, Accepted: 21 Feb 2018

Published Online: 23 Feb 2018

In-Text Citation: (Rahman \& Jusoh, 2018)

To Cite this Article: Rahman, N. A., \& Jusoh, M. A. (2018). A Review of Board of Director, Shariah Supervisory Board and Zakat Distribution Performance in Malaysia. International Journal of Academic Research in

Business and Social Sciences, 8(2), 770-779.

Copyright: (C) 2018 The Author(s)

Published by Human Resource Management Academic Research Society (www.hrmars.com)

This article is published under the Creative Commons Attribution (CC BY 4.0) license. Anyone may reproduce, distribute, translate and create derivative works of this article (for both commercial and non-commercial purposes), subject to full attribution to the original publication and authors. The full terms of this license may be seen at: http://creativecommons.org/licences/by/4.0/legalcode

Vol. 8, No. 2, February 2018, Pg. $770-779$

Full Terms \& Conditions of access and use can be found at http://hrmars.com/index.php/pages/detail/publication-ethics 


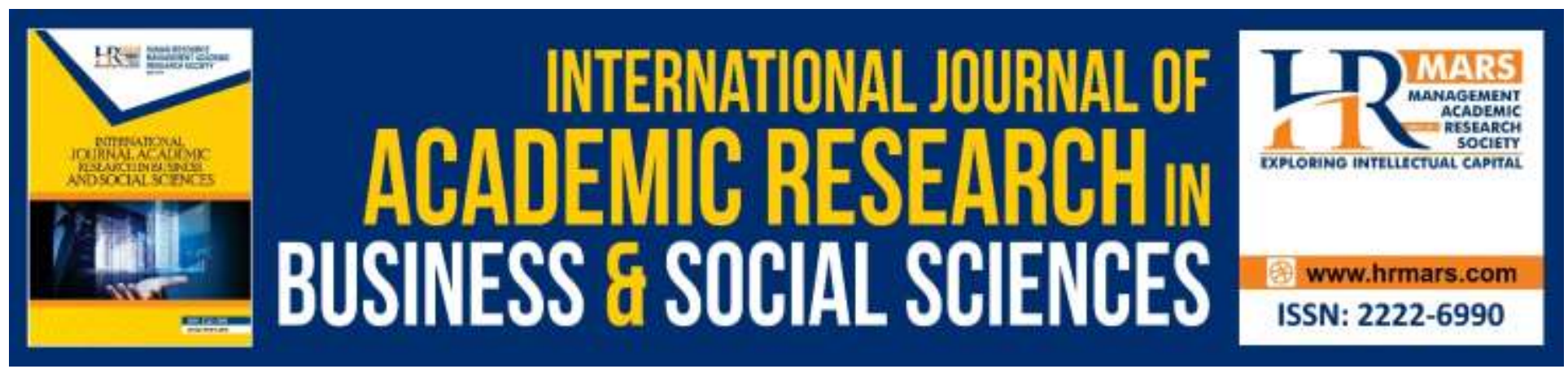

\title{
A Review of Board of Director, Shariah Supervisory Board and Zakat Distribution Performance in Malaysia
}

\author{
Norlizawati Abd Rahman, Mohd Abdullah Jusoh \\ Department of Accounting and Finance, Faculty of Accounting and Economics, Universiti \\ Pendidikan Sultan Idris, 35900 Tanjung Malim, Perak, Malaysia
}

\begin{abstract}
Recently, quality board of director is needed by organization in order to ensure the board function is well direct to meet the best performance. Meanwhile in focusing of zakat institutions, the shariah supervisory board is a committee which looking for the same objective. Both of the unit is complement each other in setting the focus to meet the aims as noteable trusted body for the collection and distribution of zakat funds. This study will focus on the distribution performance based on financial and non-financial efficiency. Besides, identify the relationship between board of director and shariah supervisory board on the distribution performance of zakat institution. Next, research hypotheses are being developed based on the previous study been reviewed and the conceptual model will be proposed. Finally, conclude with the suggestion for interest future research.
\end{abstract}

Keywords: Board of Director, Shariah Supervisory Board, Performance, Zakat Distribution

\section{Introduction}

Organizational performance essentially denotes how well a company perform in manage the resources. The performance challenges are not limited for the company but also face by several types of organization such as public and private sectors, profit and non-profit institutions, as well as co-operation. Zakat institutions as a non-profit organization are no exception on this matter. In addition, these institutions are the prime agent appointed to manage much million ringgit of zakat funds provided by payers. For this reason, another challenge for zakat institutions is related to the best practice in order to enhance their performance. Performance in this study can be referred to the efficiency of zakat distribution to recipients who are the beneficiaries of zakat fund. 
Malaysian zakat institution has been established to implement all matters related on collecting and distributing zakat to the qualified recipients (Ellany, Rizal, \& Sabri, 2014). The institution exercises the power and authority over an organization on behalf of the community it serves. In order to become the survivor of the Islamic service provider to community, the institutions have to improve zakat collection and effectively distribute the funds to recipients (Adamu \& Al Jaffri, 2016). For this reason, the quality of top management practices is significantly important in order to ensure its sustainability in long-run (Zaemah \& Norhafiza, 2016) especially in zakat institutions. Prior study by Hafizah, Azizi, and Al Jaffri (2016) in discussion about managing zakat funds, find that the equitable distribution of zakat income in society could be achieved through the effectiveness of zakat management.

The favourable development in the studies on zakat institutions has been increase in proceeds drastic of total zakat collection. (Wilayah Persekutuan had recorded of $22 \%$ increase in year 2008 over the previous year of RM206.26 million). An impressive increase of zakat collection was probably due to several factors such as easy payment methods and professional transformation of zakat institution through privatization or corporatization activities (Hairunnizam, Sanep, Mohd Ali \& Maryam, 2009). The increase of zakat collection have influence many researcher to study on the effectiveness of distribution part in order to meet the aim of recipients; namely asnaf. Rosbi and Sanep (2010) examined the effectiveness of zakat distribution on the quality of life of asnaf. Another study which focuses on distribution performance mentioned that the inefficient of zakat distribution cause by the surplus of undistributed zakat (Ellany et al., 2014). Based on these previous studies, clearly demonstrate the performance of zakat distribution is measured based on its effectiveness and efficiency. Since, performance of zakat distribution is still inefficient and did not satisfy the Muslim community, there is the gap to conduct in connection with the performance of zakat distribution efficiency.

This paper focused about the relationship between board of director (BOD) and shariah supervisory board (SSB) on the zakat distribution performance. Thus this study intends; 1 ) to evaluate the of zakat distribution performance based on financial distribution efficiency and nonfinancial distribution efficiency; 2) to identify the relationship between board of director (BOD) on the zakat distribution performance and 3) identify the relationship between shariah supervisory board (SSB) on the zakat distribution performance. These papers review the literature as well as the research hypothesis on BOD, SSB, and organizational performance on zakat distribution.

\section{Literature Review}

\section{Board of Director (BOD)}

The board of directors plays several different roles in organization, namely: monitoring and control; strategic planning; and independence (Charitou, Georgiou, \& Soteriou, 2016; Brickley \& Zimmerman, 2010; Hasnah, 2009). Some previous studies have used different measurement to determine the quality of board of director. Such measurement are the degree of freedom 
(Baysinger \& Butler, 1985); leadership (Mashayekhi \& Bazaz, 2008); decision making process (Vafeas, 1999), size (Suhaily, Maslinawati, Nurshazana, \& Zubaidah, 2016 ; Alshimmiri, 2004) knowledge (Charitou et al. \& Suhaily et al., 2016); executive interests, executive power, and elaboration opportunities (Joseph \& Ocasio, 2014); and stock ownership (Alabdullah, 2016). All of these measurements can be used as a guide in determining the quality of board of director's performance to the organization. Thus, for this study, size and expertise of board (Suhaily et al., 2016) and the number of board meetings (Yeh \& Hsieh, 2017; Khanchel, 2007) seen fit practiced for zakat institutions in order to improve their performance.

\section{Shariah Supervisory Board (SSB)}

AAOIFI Governance Standards No.1 clearly mention that shariah board refers to independent body responsible for directing, reviewing and supervising on shariah compliance as well as legal rulings in Islamic financial institutions (AAOIFI, 2005). Meanwhile, IFSB-10 review that the board member is comprised of shariah panel expert who supervise the related activity (IFSB, 2009).

Karim (1990) argues that each institution shall have the shariah supervisory board who certifies every product, finance model, and service provided by the financial institution. It also ensures that all the transactions are in strict compliance with the principles of shariah. Based on some of the above opinion, it can be concluded that the shariah supervisory board is an independent board and the members' must be expertise in Islamic financial institutions. Besides, their roles are to oversee the compliance of Islamic rules and principles in all activities of the financial institution.

\section{Organizational Performance}

There are several literature discuss about organizational performance. Some scholars defines organizational performance as a concept that measures a firm's position (May-Chiun, Mohamad, Ramayah, \& Chai, 2015; Griffin, 2003). Aliona (2016) believed that an organization evaluates the performance in order to set the focus to successes or notable achievements of the entity. Using an narrower concept, it also known as the level to measure firm's operational which fulfils the primary measures (performance objectives) and meets the needs of the secondary measures (customers) (Slack, Chambers, \& Johnston, 2010). However, the organizational performance is vary across several types of entity. It can then be concluded that organizational performance are the measurement ways in which evaluate the entity ability to meets the objective and produce the best result at the closing period.

\section{Zakat Distribution Performance}

Particularly, the issues on inefficiency of zakat distribution have affected the confidence of the Muslim community. Two evidence of the in efficiency of zakat distribution are the surplus of undistributed zakat (Eza Ellany et al., 2014) and the failure in distributing the funds to all categories of recipients with consider on their priority (Abd Halim, Mohamed Saladin, et al., 2015; Eza Ellany et al., 2014). Both the cause of this inefficiency has affected the confidence of zakat 
payers to pay funds to zakat institutions. According to Eza Ellany et al. (2014) the surplus of undistributed of zakat can be seen as an indicator of the efficiency of financial performance. Besides, the distribution of zakat by priority of recipients becomes the indicative for the efficiency on non-financial performance.

\section{Financial Distribution Efficiency}

Financial performance will be determined based on the percentage of surplus distribution compared to the total of zakat collection. The surplus distribution in this study includes the excess fund of zakat which still available for a year and not directly attributable to the year. The efficiency score for surplus of zakat distribution (FESCORE) is formed by a percentage of surplus zakat distribution fund compared to the total collection (Eza Ellany et al., 2014).

FESCORE $=\underline{\text { Total Surplus (Total Collection }- \text { Total Distribution) }}$

Total Collection

\section{Non-financial Distribution Efficiency}

Non-financial performance will be determined based on the justice of efficiency according to the recipients. The study will conduct validation of content (content validity) based on the distribution view recommended by Shafi'i madhab and form the efficiency score according to the recipients. The non-efficiency score is formed by total of differences score between the scores of Shafi'i madhab of real distribution with the scores distribution for the eight categories of Zakat institutions recipients and divided by the difference in maximum score that can be obtained by the eight categories of recipients (Hairunnizam et al., 2016; Eza Ellany et al., 2014; 2009; Mohamad Uda, 2005). The priority efficiency score of recipients (NFESCORE) formed by the interests of the recipients who must take precedence in the order as stated in the Qur'an and Sunnah, based on Imam Shafi'i madhab. The study is to verify the content validity based on the recommended distribution ratio and score based based on Shafi'i madhab (Mohamad Uda, 2005).

\section{Hypothesis}

The Relationships between Board of Director and Zakat Distribution Performance

Suhaily et al. (2016) and Yermack (1996) discovered the quality of director characteristics based on the board's size. In earlier, Alshimmiri, (2004) found large-sized organizations can improve organizational performance. This agreed by Suhaily et al. (2016) who found that the organization's performance is higher when the number of board is bigger. Besides, the board members of zakat institutions are normally consist of volunteers rather than paid professionals, the presence of professional members on the board is important (Suhaily et al., 2016).

Most of organization practices average ideal number of board members between 5 to 15 directors (OECD, 2011). Bursa Malaysia (2016) states among its core competencies are required of a director's professional expertise and always follow the rapidly changing business 
environment. Theory of dependency of resources believe that part of the expertise of the board (board capital) able to facilitate the provision of firm's resources (Hillman \& Dalziel, 2003) and improving the performance (Dalton, Daily, Johnson, \& Ellstrand, 1999). The discovery of Van Ness et al. (2010) show that the institution has a wide range of expertise is positively associated with growth and financial performance of the firm. Francis et al. (2012) found the board with financial expertise is positively associated with firm performance. Norazlina \& Rahim (2015) proposed directors with finance and shariah expertise will help to improve the efficiency of zakat institutions.

Feng, Ghosh, \& Sirmans (2005) found that institutional quality characteristics significantly associated with performance-indexed. The study assumes the board of directors that consists of features such as the size of the board ideal OECD (2011) between 5 and 15 people were restricted in line with the views of practitioners of agency theory (Nicholson \& Kiel, 2003); director of the expert in finance and sharia; and the number of board meetings are able to influence the performance of zakat distribution. Then first research hypothesis is:

$\mathrm{H}_{1} \quad$ There is significant relationship between board of directors and zakat distribution performance.

The relationships between shariah supervisory board and zakat distribution performance This study will focus on investigating the existence of the shariah supervisory board in zakat institutions. The shariah supervisory board can be trusted to act in their best way for accomplishing zakat payer's interest. The shariah supervisory board was positively associated because the institution with the shariah supervisory may have done more monitoring of transactions and checking of whether they were in compliance with shariah law (Al-shammari, 2012).

That is important to note that shariah supervisory board role is ensuring the implementation of maqasid shariah and inspecting the implementation of transaction agreement in Islamic financial institution, which also affects financial reporting (Saiful Azhar, 2010). Besides, shariah supervisory board is a very important structure in the Islamic financial institution in ensuring all the objectives of shariah governance (Mediawati, 2016). Referring to the opinions above, it can be formulated the hypothesis as follows:

$\mathrm{H}_{2} \quad$ There is significant relationship between shariah supervisory board and zakat distribution performance.

\section{Research Methodology}

The study will used secondary data sources covering the period of seven years between the years of 2010 to 2016. Generally, data relating to governance and zakat can be obtained from secondary data, namely the annual report and website of zakat institutions. However, the 
availability of this data is limited for some of zakat institution that do not publish annual reports in their website or some of the data require are not available. In this circumstance, the study will obtain data by using survey questions for the relevant data. Therefore, the multi method quantitative will be a complementary technique for data collection in the unavailability of some information from the secondary source (Seawright, 2016). Regression analysis model and OLS will be used for testing every hypothesis to meet the objectives of the second and third objectives of the study. Lastly, the method of data analysis that will be used is the Statistical Package for the Social Science (SPSS) version 22.0.

\section{A Proposed Research Model}

Based on the discussion above, there are few empirical studies that focus on the relationship between board of director and zakat distribution performance. Somehow, Norazlina and Abdul Rahim (2015) have found that the mechanism of the board of directors may lead to the efficiency of zakat institutions. Therefore, this study proposed to evaluate the relationship between boards of director complement with shariah supervisory board towards influencing zakat distribution performance which is not being discussed in other review. The proposed research model is as presented in Figure 1.

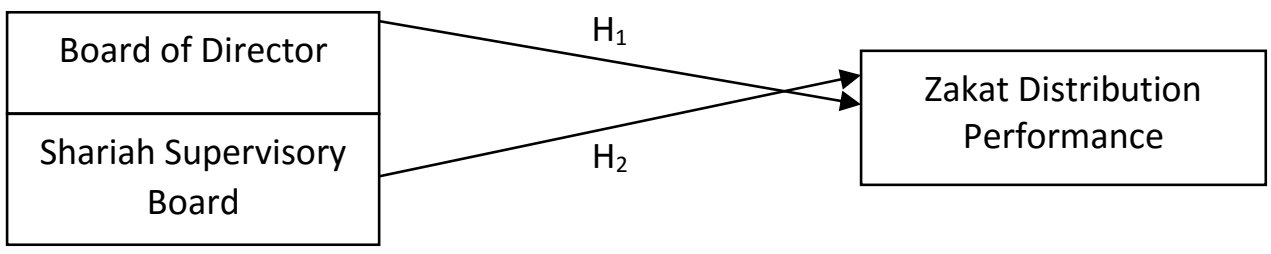

Figure 1. Proposed model of the study

\section{Conclusion}

Zakat institutions are the most trusted body by Muslim community in Malaysia as the mandate given to collect and distribute the funds of zakat. Therefore, management of zakat institutions have to be directed and managed effectively in a good manner. The quality board of directors and shariah supervisory board is important body in zakat institution to fulfil the aim of the organization. Organization itself needs to ensure that both type of board plays their roles in organization. Generally, zakat institution has to evaluate the tool to monitor and control the management behaviour of zakat institutions in order to ensure that the interests of zakat payers are met. The decision roles can be effectively implemented if the board of directors as well as shariah supervisory board are applied their ability as quality directors. In Malaysian zakat institutions, there are relatively few studies that have explored the segmentation potential of zakat recipient's expectation of board of directors and shariah supervisory board towards distribution performance. Therefore, this research should be explore more in future to order to provide an establish result between of board of director and shariah supervisory board and its relationship with zakat distribution performance. 
INTERNATIONAL JOURNAL OF ACADEMIC RESEARCH IN BUSINESS AND SOCIAL SCIENCES

Vol. 8, No.2, February 2018, E-ISSN: 2222-6990 @ 2018 HRMARS

\section{Corresponding Author}

Norlizawati Abd Rahman

Faculty of Management and Economics,

Universiti Pendidikan Sultan Idris, Tanjong Malim, Perak.

Email: norlizawatiabdrahman@gmail.com

\section{References}

AAOIFI. (2005). Accounting, Audititng and Governance Standards (for Islamic Financial Institutions). Accounting and Audititng Organization for Islamic Financial Institutions, Manama, Bahrain.

Abd Halim, M. N., Saladin, M. A. R., Rozman, M. Y., Mariam, S. A., \& Rashidah, A. R. (2015). Efficiency of Islamic institutions: Empirical evidence of zakat organizations' performance in Malaysia. Journal of Economics, Business and Management, 3(2), 282-286.

Al-shammari, B. (2012). Corporate Governance and Islamic Social Responsibility Disclosure In Kuwaiti Shariah Compliant Financial Institutions, 5-36.

Alabdullah, T. T. Y. (2016). Structure Beneficial In Emerging. International Journal of Management \& Information Systems -, 20(3), 87-94.

Aliona, B. (2016). Financial Performances Measurement Tools. Annals-Economy Series, (3), 169173.

Alshimmiri, T. (2004). Board Composition, Exectutive Remuneration, and Coprorate Performance: The Case of Reits. Corporate Ownership \& Control, 2(1), 104-119.

Baysinger, B. D., \& Butler, H. N. (1985). Corporate Governance and the Board of Directors: Performance Effects of Changes in Board Composition Corporate Governance and the Board of Directors: Performance Effects of Changes in Board Composition. Journal of Law, Economics and Organization, 1(1), 101-124.

Brickley, J. A., \& Zimmerman, J. L. (2010). Corporate governance myths: Comments on Armstrong, Guay, and Weber. Journal of Accounting and Economics, 50(2-3), 235-245.

Bursa Malaysia. (2016a). Chapter 15- Corporate Governance. Bursa Malaysia Listiing Requirement, 3(July), 1501-1508. https://doi.org/10.1017/CBO9781107415324.004

Charitou, A., Georgiou, I., \& Soteriou, A. (2016). Corporate Governance, Board Composition , Director Expertise, and Value: The Case of Quality Excellence. Multinational Finance Journal, 20(3), 181-236.

Dalton, D. R., Daily, C. M., Johnson, J. L., \& Ellstrand, A. E. (1999). Number of directors and financial performance: A meta-analysis. Academy of Management Journal, 42(6), 674-686.

Ellany, E. A. L., Rizal, M. P., \& Sabri, M. H. (2014). Prestasi Kecekapan Agihan Kewangan dan Bukan Kewangan di Kalangan Institusi Zakat di Malaysia. Jurnal Ekonomi Malaysia, 48(2), 51-60.

Feng, Z., Ghosh, C., \& Sirmans, C. F. (2005). How Important is the Board of Directors to REIT Performance? Journal of Real Estate Portfolio Management, 11(3), 281-293.

Francis, B., Hasan, I., \& Wu, Q. (2012). Do corporate boards affect firm performance? New evidence from the financial crisis. Bank of Finland Research Discussion Papers, 11.

Griffin, K. (2003). Economic Globalization and Institutions of Global Governance. Development \& 
INTERNATIONAL JOURNAL OF ACADEMIC RESEARCH IN BUSINESS AND SOCIAL SCIENCES

Vol. 8, No.2, February 2018, E-ISSN: 2222-6990 @ 2018 HRMARS

Change, 34(5), 789-808.

Hafizah, Z., Azizi, A. B., \& Ram Al Jaffri, S. (2016). Reputation, satisfaction of zakat distribution, and service quality as determinant of stakeholder trust in zakat institutions. International Journal of Economics and Financial Issues.

Hairunnizam, W., Sanep, A., Mohd Ali, M. N., \& Maryam, A. R. (2016). Prestasi Kecekapan Pengurusan Kewangan dan Pengurusan Agihan Zakat: Perbandingan Antara Majlis Agama Islam Negeri. In Persidangan Kebangsaan Ekonomi Malaysia, 8-9.

Hairunnizam, W., Sanep, A., \& Radiah, A. K. (2009). Pengagihan zakat oleh institusi zakat kepada Iapan asnaf: Kajian di Malaysia. In Seminar Kebangsaan Ekonomi Islam 2008/09 pada 10-11 Februari 2009 di APIUM, 1-17.

Hasnah, H. (2009). Kegagalan tadbir urus korporat: bagaimanakah keberkesanan mekanisme pemantauan dalaman dan luaran dapat membantu?Siri perlantikan profesor 2006 / bil. 11 .

Hillman, A. J., \& Dalziel, T. (2003). Boards of Directors and Firm Performance: Integrating Agency and Resource Dependence Perspectives. Academy of Management Review, 28(3), 383-396.

IFSB. (2009). Guiding Principles on Shari'ah Governance Systems for Institutions Offering Islamic Financial Services. Islamic Financial Service Board. Retrived form http://www.ifsb.org/standard/IFSB9_Guiding\%20Principles\%20on\%20Conduct\%20of\%20B usiness.pdf

Joseph, J., \& Ocasio, W. (2014). The Structural Elaboration of Board Independence: Executive Power, Institutional Logics, and the Adoption of CEO-Only Board Structures in U.S. Corporate Governance. Academy of Management Journal, 57(6), 1834-1858.

Karim, R. A. A. (1990). The independence of religious and external auditors: The case of Islamic Banks. Accounting, Auditing \& Accountability Journal, 3(3), 34-44.

Khanchel, I. (2007). Corporate governance: measurement and determinant analysis. Managerial Auditing Journal, 22(8), 740-760.

Mashayekhi, B., \& Bazaz, M. S. (2008). Corporate Governance and Firm Performance in Iran. Journal of Contemporary Accounting \& Economics, 4(2), 156-172.

May-Chiun, L., Mohamad, A. A., Ramayah, T., \& Chai, W. Y. (2015). Examining the effects of leadership, market orientation and leader member exchange (LMX) on organisational performance. Engineering Economics, 26(4), 409-421.

Mediawati, E. (2016). Research Article Internal Control and Sharia Supervisory Board Role in. International Journal of Recent Advances in Multidisciplinary Research, 3(8), 1730-1732.

Uda, M. K. (2005). Zakat Teori, Kutipan dan Agihan. Kuala Lumpur: Utusan Publication \& Distributors Sdn Bhd.

Nicholson, G. J., \& Kiel, G. C. (2003). Board Composition and Corporate Performance: How the Australian Experience Informs Contrasting Theories of Corporate Governance. Corporate Governance: An International Review, 11(3), 189-205.

Norazlina, A. W., \& Rahim, A. R. (2015). Efficiency of zakat institutions and its determinants. H A El-Karanshawy et Al. (Eds.), Access to Finance and Human Development - Essays on Zakah, Awqaf and Microfinance, 1, 33-42.

OECD. (2011). Reform priorities in Asia: taking corporate governance to a higher level. Retrieved 
INTERNATIONAL JOURNAL OF ACADEMIC RESEARCH IN BUSINESS AND SOCIAL SCIENCES

Vol. 8, No.2, February 2018, E-ISSN: 2222-6990 @ 2018 HRMARS

from https://www.oecd.org/corporate/ca/49801431.pdf

Rosbi, A. R., \& Sanep, A. (2010). Pengukuran Keberkesanan Agihan Zakat; Perspektif Maqasid alSyariahOrganized by. In $7^{\text {th }}$ International Conference The Tawhidi Epistemology: Zakat And Waqf Economy, 448-460.

Azhar, S. R. (2010). Shariah parameters reconsidered. International Journal of Islamic and Middle Eastern Finance and Management, 3(2), 132-146.

Adamu, S. M., \& Al Jaffri, R. S. (2016). Determinants of trust on zakat institutions and its dimensions on intention to pay zakat: A pilot study. Journal of Advanced Research in Business and Management Studies, 3(1), 40-46.

Seawright, J. (2016). Multi-Method Social Science: Combining Qualitative and Quantitative Tools. Cambrige Univercity Press.

Slack, N., Chambers, S., \& Johnston, R. (2010). Operations Management. Group (6 $6^{\text {th }}$ ed.). Prentice Hall.

Suhaily, H., Maslinawati, M., Nurshazana, Z. Z., \& Zubaidah, Z. A. (2016). Corporate Governance Factors Affecting Donation: Evidence from Charitable Organizations in Malaysia. International Journal of Economics and Financial Issues, 6(6), 149-153.

Vafeas, N. (1999). Board meetings, committee structure, and firm value. Journal of Financial Economics, 53(1), 113-142.

Yeh, Y. M. C., \& Hsieh, W.-C. (2017). Does Board Supervisory Quality Enhance Corporate Social Performance?-Evidence from Taiwanese Listed Firms. Asian Journal of Finance \& Accounting, 9(1), 68.

Yermack, D. (1996). Higher market valuation for firms with a small board of directors. Journal of Financial Economics, 40(1494), 185-211.

Zaemah, Z., \& Norhafiza, N. (2016). Addressing Governance Issue in Islamic Real Estate Investment ( I-Reits ): A Case Study For OIC Country -Malaysia, 1(1), 60-75. 